\title{
Correction to: Serum IFN- $\gamma$ levels predict the therapeutic effect of mesenchymal stem cell transplantation in active rheumatoid arthritis
}

Yi Yang ${ }^{1,2+}$, Xiao He ${ }^{1 \dagger}$, Rongseng Zhao ${ }^{1}$, Wei Guo ${ }^{1}$, Ming Zhu' ${ }^{1}$, Wei Xing ${ }^{1}$, Dongpo Jiang ${ }^{3}$, Chongyang Liu ${ }^{2 *}$ and Xiang $\mathrm{Xu}^{1 *} \mathbb{D}$

\section{Correction to: J Transl Med 16:165 (2018)} https://doi.org/10.1186/s12967-018-1541-4 In the original publication [1] there was an error in Figure 3c. The 24 and 48 FACS plot were duplicated in Figure $3 \mathrm{c}$ control due to human error.
The updated 24 and 48 FACS plots are published in this correction article as Fig. 1 along with the original/incorrect figure (Fig. 2). The full captions are available via the original article. The original article has been updated.

(c) The Author(s) 2021. This article is licensed under a Creative Commons Attribution 4.0 International License, which permits use, sharing, adaptation, distribution and reproduction in any medium or format, as long as you give appropriate credit to the original author(s) and the source, provide a link to the Creative Commons licence, and indicate if changes were made. The images or other third party material in this article are included in the article's Creative Commons licence, unless indicated otherwise in a credit line to the material. If material is not included in the article's Creative Commons licence and your intended use is not permitted by statutory regulation or exceeds the permitted use, you will need to obtain permission directly from the copyright holder. To view a copy of this licence, visit http://creativecommons.org/licenses/by/4.0/. The Creative Commons Public Domain Dedication waiver (http://creativecommons.org/publicdomain/zero/1.0/) applies to the data made available in this article, unless otherwise stated in a credit line to the data. 


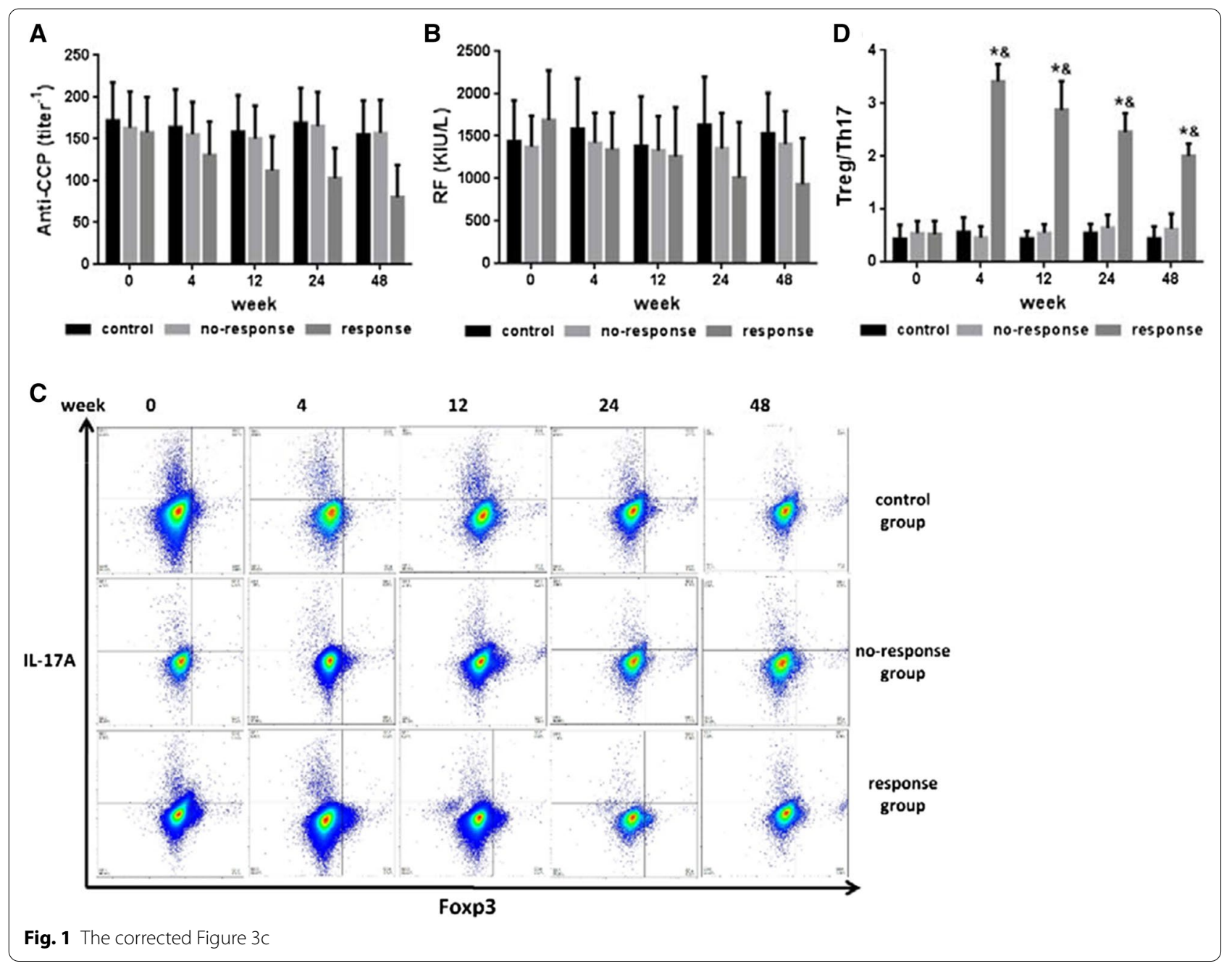



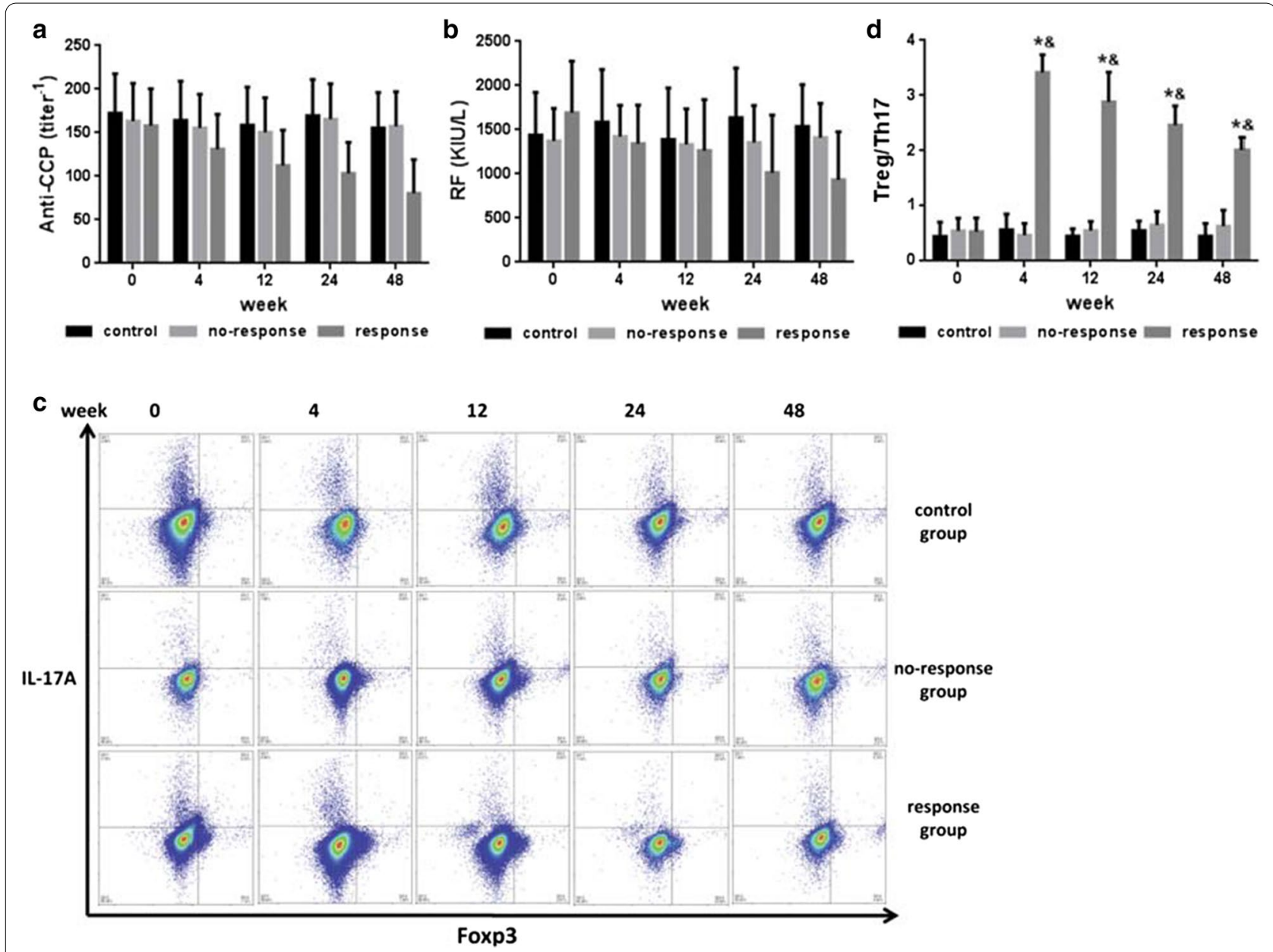

Fig. 2 Incorrect Figure 3 as originally published

\section{Author details}

'First Department, State Key Laboratory of Trauma, Burn and Combined Injury, Daping Hospital and Research Institute of Surgery, Third Military Medical University, Chongqing 400042, People's Republic of China. ${ }^{2}$ Department of Rheumatology and Clinical Immunology, Daping Hospital and Research Institute of Surgery, Third Military Medical University, Chongqing 400042, People's Republic of China. ${ }^{3}$ Department of Critical Care Medicine, Daping Hospital and Research Institute of Surgery, Third Military Medical University, Chongqing 400042, People's Republic of China.

Published online: 23 September 2021

\section{Reference}

1. Yang Y, He X, Zhao R, Guo W, Zhu M, Xing W, Jiang D, Liu C, Xu X. Serum IFN- $\gamma$ levels predict the therapeutic effect of mesenchymal stem cell transplantation in active rheumatoid arthritis. J Transl Med. 2018;16:165. https://doi.org/10.1186/s12967-018-1541-4.

\section{Publisher's Note}

Springer Nature remains neutral with regard to jurisdictional claims in published maps and institutional affiliations. 